\title{
Europeanisation in the Societal/Trans-National Realm: What European Integration Studies Can Get Out Of Analysing Football
}

\section{Alexander Brand \& Arne Niemann}

\begin{abstract}
This article combines our empirical analysis concerning the impact of EU- and European-level developments on socio-economic patterns in the field of German football with the growing Europeanisation research agenda in EU Studies. Going beyond the traditional top-down (and bottom-up) approaches dominating this field of study, we seek to contribute to this debate by focusing on what we term the 'societal/trans-national' dimension of Europeanisation. This allows us to draw attention to societal spheres and transnational agency as important aspects/properties of change in Europeanisation processes. Through analysing five cases within the area of German football, we not only want to shed some light on an under-researched field of study for political scientists interested in Europeanisation. We also aim at exploring the applicability of systemising factors of the Europeanisation process derived from the analysis of political contexts to other areas of social interaction in order to capture hitherto neglected processes.
\end{abstract}

'EUROPEANISATION' HAS BECOME A FOCAL POINT OF DISCUSSION IN EUROPEAN integration studies. Although the term is used in different ways to describe a variety of phenomena, its meanings have usually been restricted to (in a strict sense) processes of domestic political changes caused by European integration. Most studies have emphasised top-down dynamics inherent in this particular notion of Europeanisation, whereas bottomup and/or transnational processes and attempts to analyse their interplay have entered the debate only recently. We seek to contribute to this debate by focusing on what we describe as the 'societal/trans-national' dimension of Europeanisation: this dimension encapsulates (1) the level and sphere of change; and (2) the type of agency generating or resisting change.

In this paper, we seek to analyse the impact of European-level governance - the case law of the European Court of Justice and the Community's competences in the area of competition policy - on German football. More particularly we will look at the nationality issue related to the Bosman ruling (case 1), the new transfer regime resulting from the Bosman ruling (case 2), and the issue of broadcasting rights (case 3). In the broader context, additional factors are considered which less clearly relate to the European integration process, such as the development of the Champions League (case 4) or the emergence of transnational groupings like the G-14 (case 5). Taken together, these processes add up to the ongoing 'Europeanisation' of (German) football.

Earlier versions of this paper have been presented at the Workshop "Sport and the European Union, 10 Years After Bosman: Situation and Perspectives", Loughborough University (UK), 30 June \& 1 July 2006, and the European Union Studies Association (EUSA) conference, Montréal, 17-19 May 2007. We would like to thank the participants of the above events, Frank Schimmelfennig, Osvaldo Croci and two anonymous referees for their comments on previous drafts.

ISSN 1815-347X online - Brand, A. and Niemann, A. (2007). 'Europeanisation in the Societal/Trans-National Realm: What European Integration Studies Can Get Out Of Analysing Football', Journal of Contemporary European Research, Vol. 3, No. 3, pp. 182-201. 
By analysing five cases within the realm of German football, we not only want to shed some light on an under-researched field of study for political scientists interested in Europeanisation, but we also want to explore the general applicability of Europeanisation factors (sources, dynamics and level of change), which have been derived mainly from the analysis of more politico-economic contexts, to explain dynamics in societal, that is rather non-political, contexts. ${ }^{1}$ This way we may also clarify potential 'blind-spots', for example dynamics and interrelated mechanisms in Europeanisation processes that have been largely ignored by traditional analyses). Our empirical focus is salient as it represents a social context, which forms an important and conscious part of citizens' lives (rather than an abstract and inaccessible sphere). This may enable us to gain a deeper understanding of Europeanisation regarding citizens' life worlds.

Our article will first elucidate the concept of Europeanisation and specify our understanding of the term. Secondly, we will outline the societal/transnational dimension of Europeanisation. The third section attempts to formulate some systemising factors of the Europeanisation process which guides our empirical analysis of five sub-cases related to German football that will follow thereafter.

\section{The concept of Europeanisation}

Research on Europeanisation has gradually increased since the mid-1990s and has developed into an academic growth industry over the last decade. In the field of political science alone, the term Europeanisation is used in a number of different ways to describe a variety of phenomena and processes of change (Olsen 2002). Most frequently Europeanisation is referred to as domestic change, in terms of policy substance and instruments, processes of interest representation and policy style, as well as (political) structures and institutions (Radaelli 2000). As a field of inquiry, Europeanisation merits continued systematic academic attention. The Europeanisation research agenda arguably focuses on a set of very important research questions, related to where, how, why, and to what extent domestic change occurs as a consequence of EU integration and governance at the European level. In addition, compared to several decades where European integration studies has focused on explaining and describing the emergence and development of a supranational system of European cooperation, research on Europeanisation is still in its infancy.

As a starting point, Europeanisation is understood here as the process of change in the domestic arena resulting from the European level of governance. However, Europeanisation is not viewed as a unidirectional but as a two-way-process which develops both top-down and bottom-up. Top-down perspectives largely emphasise vertical developments from the European to the domestic level (Ladrech 1994; Schmidt 2002). Bottom-up accounts stress the national influence concerning European level developments (which in turn feeds back into the domestic realm). This perspective highlights that EU member states are more than passive receivers of European-level pressures. They may shape policies and institutions on the European level to which they have to adjust at a later stage (Börzel 2002). By referring to Europeanisation as a two-way process our conceptualisation underlines the interdependence between the European and domestic levels for an explanation of Europeanisation (processes). In contrast to a unidirectional top-down usage of the concept, studying Europeanisation as a two-way process entails certain disadvantages in terms of (waning) conceptual parsimony and methodological straightforwardness. However, we argue that these problems are outweighed by a greater ability to capture important empirical phenomena. It has convincingly been shown, for example, that Member States responses to Europeanisation processes feed back into the European level of decision-

\footnotetext{
1 'Football' certainly constitutes a 'non-political' sphere from the perspective of much International Relations and Political Science literature, i.e. it is still an 'exotic' topic to deal with as a political scientist. This by no means implies that we regard football as constituting a non-political sphere, to the contrary. Most works on the political nature of football (and sports generally) are, however, written by sport scientists, historians and journalists, see for instance Shaw (1987), Wagg (1995), Havemann (2005).
} 
making. European/EU policies, institutions and processes cannot be taken as given, but are, at least to some extent, the result of domestic political preferences and processes which are acted out on the European level (Börzel 2001, 2002; Dyson 1999).

However, as will be further specified later on, framing Europeanisation processes as the interplay between the European and the domestic realm still constitutes a considerable simplification, largely because transnational (non-EU)-level developments may provide important properties of Europeanisation. In addition, it should be pointed out that for us Europeanisation does not equate 'EUisation'. Rather the EU is only part (albeit an important one) of the wider fabric of cross-border regimes in Europe in which other (transnational) institutions and frameworks, also play a role. Hence the EU is not the monopoly source and channel of Europeanisation (Wallace 2000). This may include institutional arrangements at the European level which are related to European cooperation in a broader sense, such as the Council of Europe (COE) or the Organisation for Security and Co-operation in Europe (OSCE) on the political level, but also organisations such as the Association Européenne des Conservatoires (AEC) and the European Football Association (UEFA) on the societal level.

While working with a fairly wide notion of Europeanisation, it is important to clearly delimit the concept in order to avoid the danger of overstretching it. For instance, we would reject 'the emergence and development at the European level of distinct structures of governance' as an appropriate definition of Europeanisation (Risse et al. 2001: 3; emphasis added). Although our conceptualisation relates to multi-level processes, the core focus remains on the process of change in the domestic arena. In addition, Europeanisation should not be confused with 'harmonisation' and also differs from 'convergence'. Europeanisation may lead to harmonisation and convergence, but this is not necessarily the case. Empirical findings indicate that Europeanisation may have a differential impact on national policy-making and that it leaves considerable margin for domestic diversities (Héritier et al. 2001; Caporaso and Jupille 2001). Moreover, as pointed out by Radaelli (2000: 5 ) there is a difference between a process (Europeanisation) and its consequences (e.g. potentially harmonisation and convergence).

\section{The societal/trans-national dimension of Europeanisation}

The societal/trans-national dimension of Europeanisation encapsulates two elements: (1) the level and sphere of change; on other words, that regulation and jurisdiction from Brussels is likely to induce some adaptational pressure not only at the political level but also in societal contexts (e.g. the realm of sport, and for our purpose, football); (2) the type of agency generating or resisting change. This latter dimension aims at capturing some trends, which can be traced in analysing how societal actors are either reacting towards attempts of regulation by the EU or creating transnational spaces that in turn impact on the governance of football.

As pointed out in the previous section, highlighting the societal/transnational dimension contributed to our rather broad conceptualisation of 'Europeanisation'. Concept-stretching has to be justified, given the potential loss of analytical clarity (Radaelli 2000). We argue that accounting for the societal and transnational dimension is justified, as otherwise interesting fields of study and important dynamics between the European and the domestic levels would go largely unnoticed.

As for the sphere of change, in contrast to most studies we chose to study a subject (football, or sports in general), which is seemingly 'non-political'.2 What makes such a case interesting, besides the fact that it constitutes a more politicised realm than commonly assumed, is that it represents a social context, which forms an important and conscious part of citizens' 'life world'. It is therefore a context, which is realised by many people as part of their lives - not a supposedly abstract and inaccessible sphere of politics. To study processes of

\footnotetext{
${ }^{2}$ See n. 1
} 
Europeanisation at this societal level thereby should allow for a deeper understanding of any Europeanisation regarding citizens' life worlds. Although this is not a major theme in our paper, the question of a Europeanisation of life worlds could lead to interesting insights in the eventual formation of a common European identity; a subject much debated in the current literature (Risse 2004; Mayer and Palmowski 2004). Aside from these considerations, to study Europeanisation dynamics within a societal field like 'football' may be salient for two reasons. First, it allows us to explore the applicability of Europeanisation concepts (sources, dynamics and level of change), which have been derived mainly from the analysis of more political contexts to non-political (societal) contexts. Second, our study may clarify potential 'blind-spots', such as dynamics and interrelated mechanisms in Europeanisation processes that have been largely ignored by traditional analyses, which have mainly dealt with political issues.

Although it would be wrong to assert that 'transnational dimensions' of Europeanisation have only rarely been mentioned, the concept of 'transnationalism' itself is less frequently specified and illustrated empirically in Europeanisation studies. ${ }^{3}$ The transnational quality of relationships is often merely stated or an ongoing transnationalisation within EU-Europe is simply assumed (see Menz 2003, Winn 2003, Feron 2004). Yet, it is questionable whether the debate on concepts of transnationalism and transnational actors in the discipline of International Relations ${ }^{4}$ offers any sensible starting points for our approach, mainly because this debate is 'still primarily concerned with proving against a state-centered picture of world politics that [transnational actors] matter' (Risse 2002: 268). In the context of (European) integration studies, scholars working in the transactionist, neofunctionalist or supranational governance perspective have of course somewhat gone beyond that and developed accounts of transnational dynamics (see for example Deutsch 1957; Haas 1958; Stone Sweet and Sandholtz 1997; and Niemann 2006). However, their focus was above all on the development of cooperation, institutions and policies at the supranational level that is (European) integration, rather than Europeanisation with its primary focus on change in the domestic arena.

While not diverging from a common definition of 'transnationalism', our concept also encompasses actors that have been less analysed in the current literature which heavily focuses on either non-profit NGOs or profit-driven multinational corporations. We define 'transnational actors' as societal actors in a broad sense, who coordinate their actions with societal actors from other national contexts in Europe, thereby creating common, transnational reactions towards EU institutions and/or creating trans-national institutions. Transnationalism within Europe in our approach therefore rests on transboundary networks of actors, whose interests and perceptions are either aggregated or amalgamated within these networks and institutions. Societal governance networks across states have undoubtedly preceded the Europeanisation processes described here. That is, there have been supranational sports bodies - the European Football Association UEFA (founded in 1954) and its global counterpart FIFA (1904) - formed of delegates from national associations. However, as we aspire to show, Europeanisation processes from the 1990s onwards have induced a new quality of transnational agency. ${ }^{5}$

To speak of a 'societal/transnational dimension' of Europeanisation in the end means to pay tribute to the interrelatedness of the sphere of change and the type of agency: football as a societal sphere is characterised by a growing transnationalisation, as will be shown. Opening Europeanisation as a field of inquiry up to this dimension further adds to the awareness of the complexity of Europeanisation processes and may also incorporate the consciously perceived 'Europeanised' life worlds of European citizens into the academic debate.

\footnotetext{
${ }^{3}$ But see Kohler-Koch (2002), who sketches out several dimensions of transnationalism within the complex system(s) of European governance.

${ }^{4}$ For an overview of this debate see Risse (2002).

${ }^{5}$ At times, these associations were used as infrastructures for the articulation of certain goals, at other times they were consciously ignored. Indeed, it would be an interesting study on its own to analyse more thoroughly the relationship between the national associations, the supranational associations and political as well as juridical decision-making on the European level.
} 


\section{The Europeanisation process: some systemising factors}

Different typologies can be introduced in order to systematise Europeanisation processes. This section will formulate several systematisations, which are to some extent derived from the existing literature. Subsequently, our empirical analysis will explore to what extent such typology of the Europeanisation process makes sense, also in terms of the more transnationally driven sub-cases. To begin with, the basic sources of Europeanisation - topdown, bottom-up and transnational/societal - have already been sufficiently pointed out above and thus require no further explication here. Although these sources of Europeanisation often substantially interact, certain tendencies in terms of these dimensions can usually be ascertained (Lodge 2002).

Secondly, we can differentiate in terms of the level of strength of Europeanisation sources and pressures. As for top-town processes, a number of indicators can be suggested. The legal bindingness of EU provisions probably constitutes the best indicator for the force of topdown pressures (Vink 2002: 9-10). Yet, Europeanisation is not confined to legally binding EU provisions. It may be carried by more cognitive or ideational mechanisms. Although termed the 'weakest' Europeanisation trigger (Knill 2001: 221), the 'framing of domestic beliefs and expectations' still seems to drive Europeanisation processes forward to some extent (Knill and Lehmkuhl 2002: 258). In addition, the degree of clarity, both in terms of legal argumentation (concerning ECJ rulings) and in terms of legal competence (regarding exclusive or shared competence in the case of Commission involvement) influences the weight of downwards adaptational pressures. Ambiguity in these respects adversely affects Europeanisation dynamics. Moreover, the level of uniformity of reaching a decision at the European level - for example, in the Council or between the Council and the European Parliament on legislative acts, or in the Commission concerning decisions in the area of competition policy - also impacts on the strength of top-down Europeanisation sources and pressures. It can be assumed that, generally speaking, more uniform and consensual decisions at European level may have a more significant Europeanisation effect than rather contested EU decisions. As for bottom-up or transnational/societal Europeanisation, indicators regarding the strength of processes seem less obvious and perhaps more limited at this stage of inquiry. However, for example the existence of alternative (policy) venues or of credible exit options from prevailing arrangements and, more generally, the possibility of challenging existing regimes (when undesired policy externalities arise) condition the strength of such Europeanisation dynamics (Lodge 2002).

Our third categorisation concerns reactions to initial Europeanisation pressures. Broadly speaking, one can distinguish between reactions on two levels: the level of policy formulation and the level of implementation (Bugdahn 2005: 183). The type of reaction in terms of formulation and implementation depends on several factors, such as prevailing norms and preferences on the part of those affected or addressed by the initial Europeanisation pressures - and partly overlapping with actors' preferences - the goodness of fit, that is the compatibility between the (domestic) status-quo and newly induced (EU) requirements. On the level of (policy) formulation, we suggest that reactions to primary Europeanisation can take on different forms: (1) 'support', when affected/addressed actors back new requirements; (2) 'acquiescence', when agents simply accept the changes stemming from Europeanisation; (3) 'engagement/intervention', when actors seek to modify or reduce adaptational pressures; (4) 'confrontation', when actors try to resist or escape initial Europeanisation pressures. The degree of misfit can be assumed to gradually increase on this continuum.

Our fourth element systematising the Europeanisation processes is the strength of reaction to initial Europeanisation pressures. The impact of such responses will depend on several factors, one of which is access to government/policy-makers and the strategic position in, or 'membership' of, policy/advocacy networks. Another factor is organisational strength, made up, for instance, of material resources, the degree of centralisation and cohesiveness, effective management, etc. (Menz 2003). 
Finally, the degree of change can be categorised. Drawing on Lodge (2002) and Radaelli (2004) who themselves drew on earlier writings, three main forms concerning the impact of Europeanisation pressures are suggested here: (1) 'system maintenance', which is characterised by a lack of change or the rejection of new requirements; (2) 'adjustment', where existing policy cores are not challenged, but some non-fundamental changes are absorbed and new layers may be added to the regime; (3) 'transformation', which denotes paradigmatic or core policy changes. Our empirical data will subsequently be examined, as far as possible, with regard to the above categorisations making up Europeanisation processes, such as sources, strength of initial pressures, reaction, strength of reaction, and degree of change.

Our empirical analysis is based on process tracing (Keown and George 1985), which has been put into practice through triangulation across different data sources (official documentation, semi-structured interviews, secondary literature and major media). As for the interviews, we conducted ten background/in-depth expert interviews with leading officials of German national as well as club football and leading sport journalists from 2004 to 2005. For our study, we have chosen to examine five different cases. These ensure variation concerning the degree of EU/European level incentives/pressures in order to be able to explore the plausibility of our systematisations across a wide range of different scenarios and so as to be capable of examining the causal relevance of the EU/European level. No or little variation in terms of EU pressures may not allow us to ascertain any positive degree of causality (Collier 1995). Our first three sub-cases - (1) Bosman I: the nationality issue; (2) Bosman II: the transfer regime; (3) broadcasting - are characterised by rather top-down (EU) pressures, albeit to varying degrees, while the last two sub-cases - (4) Champions League; (5) G-14 - are more induced by bottom-up and transnational rationales.

\section{Case 1 - The Bosman Ruling I: The Nationality Issue}

Some important trends in German football during the last decade can be interpreted as symptoms of an ongoing Europeanisation. This is because a whole complex of such trends the increased influx of foreign-born players, attempts to restrict their numbers as well as to promote young German talents, and the search for a new 'transfer regime' - has its roots in the seminal 'Bosman ruling' of the European Court of Justice (ECJ) in 1995.

The provisions in the Treaty establishing the European Community, secondary legislation, Community policies and decisions all had an increasing impact on sport throughout Europe in the last decade, although 'sport' has never been among the core competences of the EC/EU (Ducrey et al. 2003: 32). Traditionally, sport as well as football in all its aspects (organisation of events, establishment and enforcement of rules etc.) has traditionally been regulated by a set of autonomous, interrelated organisations, in the case of football by clubs, national leagues and associations, several regional federations and one worldwide football federation (Croci 2001: 2). During the 1990s, however, football increasingly came to be recognised as an economic activity by EU institutions like the Commission and the European Court of Justice, and thus as an activity, which had to be regulated like any other industry according to the rules of the Community.

The Bosman ruling of the ECJ in 1995 in its essence consisted of two general findings, which had been derived from EU law concerning the free movement of people within the European Union and competition law, albeit it only drew on the former. The two findings were: first, the traditional transfer system with transfer fees to be paid for out-of-contract players infringed upon the right of every European (worker) to move freely under Article 48 of the Treaty of Rome (TEC) and thus had to be abolished; and second, 'nationality restrictions' as a means to limit the number of foreign players in a football club were ruled illegal in so far as they discriminated against players from countries within the European Union (Foster 2000: 42).

Football in Germany has been affected by both aspects, although one could claim that the latter one has had a more 'visible' effect for the whole football community. To abolish 
general nationality restrictions ${ }^{6}$ and to open up the market for players from all other countries within the EU already had an in-built tendency to increase the number of foreignborn players. The German Football Association (DFB), however, liberalised even further and expanded the right to play professional football in Germany without being considered a foreigner not only to EU residents (so-called EU-Ausländer) but to all players living within the 51 other member states of the European Football Association (UEFA). Thus in German football, after Bosman the status of EU-Ausländer really meant UEFA-Ausländer and EU resident meant UEFA resident, at least concerning the two professional leagues.?

How to account for this extension, which has been exceptional in Europe? One line of argumentation refers to the special socio-political situation in Germany after re-unification: the DFB and its leading actors were still influenced and impressed by the dramatic political changes in Europe and the 'unification' of the continent that had taken place a few years before. They simply 'did not want to erect new walls or barriers', especially towards national associations in Central and Eastern Europe, which had strong ties to the DFB. ${ }^{8}$ In a similar vein, some actors were convinced that the ongoing process of European integration would render any differentiation between certain types of Europeans meaningless sooner or later. ${ }^{9}$ Although the extension may show that 'football sometimes is more political than people think ${ }^{\prime 10}$, there was also an element of pragmatic (and even visionary) thinking to it, because the decision taken by the DFB in the end prevented non-EU European footballers from taking legal action against this discrimination. ${ }^{11}$ Another explanatory factor is that this extension created a bigger market for German football clubs to sign players, especially players from Central and Eastern Europe. ${ }^{12}$ After Bosman a central source of financing for clubs - transfer fees for out-of-contract players - ceased to exist. In addition, German clubs are subject to a relatively strict licensing procedure, which means they have to pursue fairly sound economic policies. Hence, opening up the market especially towards Eastern Europe also had a compensatory effect for German football clubs, as signing players from Poland or the Balkans was in general less expensive. Both explanations - the socio-political climate as well as an interest of the clubs to improve their position among European competitors - can be seen as complimentary rather than mutually exclusive.

It is hardly surprising that this decision led to a surge of players coming to Germany from all over Europe; a claim that can be substantiated by looking at the developments of the First Bundesliga. At the beginning of the 1990s - before Bosman - the shares of the respective players' groups of the overall number of players exhibit a fairly stable pattern: approximately 80 per cent German-born players, 12-14 per cent UEFA residents (without Germans), 5-7 per cent non-UEFA residents. After Bosman and the decision of the DFB to count all players from UEFA member-states as EU residents, we can easily detect some important changes in the composition of the players. Firstly, the share of German-born players has steadily decreased (accounting for 50 per cent in 2005). Secondly, the share of UEFA residents as well as the share of players from other continents has substantially increased, although the share of non-UEFA residents remains relatively small (between 12 and 14 per cent in 2003 and 2004)

\footnotetext{
${ }^{6}$ Before the transposition of Bosman, the so-called ' $3+2$ rule' applied. It allowed European teams to field three foreign players and two 'assimilated players', i.e. who had played in the respective country for at least five consecutive years.

7 This extension has not become effective for junior or amateur teams, where EU resident really means EU resident.

${ }^{8}$ Interview with Dr. Theo Zwanziger, then-Managing President of the DFB, by telephone, January 2005.

${ }^{9}$ Interview with Gerhard Mayer-Vorfelder, then-President of the DFB, by telephone, January 2005.

${ }^{10}$ Interview with Theo Zwanziger, Managing President of the DFB, January 2005.

11 Only recently, the ECJ has issued a ruling concerning the discrimination of a European but non-EU professional player (from Russia), who had been restricted from playing by a nationality clause in Spain. The ECJ ruled this discrimination illegal on the grounds of the Partnership and Cooperation Agreement between Russia and the EU, see e.g. Frankfurter Allgemeine Zeitung, 13 April 2005. The 'Simutenkow ruling' from 2005, from this perspective, can be regarded as the logical extension of the 'Bosman ruling'.

12 In general, Bosman of course led to increased commercialisation and competitive pressure on behalf of the clubs.
} 
compared to that of UEFA residents (up to 38 per cent in 2005).$^{13}$ Although the decision to open the market for all Europeans has been rather liberal, the DFB did not fully liberalise until 2006/07, when it decided to abolish any limit on foreign players in professional clubs, while 12 German players have to be signed ('local player rule' of UEFA).

The shortage of young and talented German football players, which became obvious at the end of the 1990s, was at least to some part attributed to Bosman and its implementation in Germany. Thus, the carefully directed promotion of young and talented players eligible for German national teams has become a real concern of the DFB in the wake of Bosman. What is more, the DFB - in accordance with the German Football League (DFL) - has also tried to steer the development by establishing certain rules for professional and amateur clubs, which aim at developing and protecting young German players as far as possible within the limits of public national and European law. Every club in the Bundesliga has to maintain a training centre for young players (Nachwuchsleistungszentrum) in order to comply with the licensing rules. Amateur clubs of professional teams have become full U23-teams since 2005 (which means that only three players aged 23 or older can be fielded). Parallel to these measures, the number of non-EU players in German amateur teams has been cut back from up to six (2002) to three (2004). This kind of 'steering policy' within the association is complemented by the policies of the German Ministry of the Interior, which in 2002 issued a directive that in effect ruled that a non-EU player will not get a work permit in Germany unless he is signed by a team in the (first and second) Bundesliga. In 2003, the follow-up to this directive specified that non-EU players must be signed to play in the first team and must not play in the amateur teams of the professional clubs. ${ }^{14}$

In sum, the nationality-related part of Bosman generated strong pressure for change on the German FA. It led to a mixed reaction of the DFB: there have been counter-reactions of course, but no strong, full-fledged counter-pressure to European institutions. Transposition has been varied: progressive (the decision to extend the definition of 'EU resident') and more conservative (measures to promote German talents). Overall, the nationality issue of the Bosman ruling (along with the 'progressive' elements of its implementation) changed the structures and the landscape of German football. The make-up of the Bundesliga has become above all less German, more international, and more European in a wider sense. This degree of change is thus most aptly captured by the notion of 'system transformation'.

\section{Case 2 - Bosman II: The new 'transfer regime'}

As has been said above, the Bosman ruling not only dealt with the 'nationality question', it also stated that the traditional transfer system had to be completely revised, since the core of this system - the payment of transfer fees for out-of-contract players - had been found to infringe upon the right of free movement within the EU. Since the transfer system was internationally agreed upon and laid down through FIFA, it became clear during the second half of the 1990s that this part of Bosman was not just (EU- or UEFA-) European business, but could and had to lead to a revision of the whole international transfer system. First and foremost the Commission pushed this view and suggested that football constituted a normal business activity to be regulated according to competition law. By contrast, the national and regional associations as well as FIFA tried to promote their view that football and sport fulfil special social functions and therefore had to be treated differently. As Parrish (2003) has shown, these actors as well as others - clubs, leagues, media, and lawyers - have formed 'advocacy coalitions' to promote their views in the negotiation process. The overhaul of the international transfer system has been a long process, in which all actors tried to influence the other side on several occasions. The uncertainties sketched above thereby led to the protraction of this process, since they created some room for manoeuvre for the national

\footnotetext{
13 These data concern the number of players fielded in the First Bundesliga 1992-2005. Data obtained from IMP AG Ismaning/Germany. For a more detailed account see Niemann and Brand (2008 forthcoming).

${ }^{14}$ Kicker, 27 January 2003; EU player in this regard means a player born within a member state of the EU, where the rights concerning the free movement of labour do apply.
} 
associations and FIFA/UEFA. Although the Commission finally pushed them to the table by threatening another ruling through the ECJ in 2000 (Croci 2001: 7), the 'new transfer regime' agreed upon in 2001 suggested that the European Commission in some parts had loosened its demands and abandoned its purism. This is especially true with regard to contract stability (vs. 'normal' periods of notice), which still has to be guaranteed except for narrowly defined situations, and the introduction of a new system of training compensations (as a 'quasi'transfer fee) for players aged under 23 to encourage and reward training efforts of clubs (Weatherill 2003: 68). This change in attitude of the Commission merits attention and needs to be explained. How was it possible that '[a]fter reaching the compromise agreement with the European Commission [in 2001], FIFA President Blatter, ... publicly thanked Competition Commissioner Mario Monti with words that gave the impression that the Commission had simply acted as a consultant to FIFA to improve its transfer rules' (Croci/Forster 2004: 16)?

One could reason that the Commission has been persuaded by the arguments concerning the peculiarities of organising football and the presumed consequences of a fully liberalised transfer regime put forth through FIFA (and the DFB as well). Indeed, some leading German football officials interpret the negotiation process with the Commission to some degree as a successful act of lobbying in the sense of creating more awareness within the Commission for possible disastrous consequences of strict liberalisation; for example, the inoperability of leagues because of highly volatile player markets. ${ }^{15}$ There are indeed some indicators that underscore this reasoning, since the Commission gradually reformulated its position throughout the 1990s, as can be seen in the so-called Helsinki Report on Sport from 1999 (Brown 2000: 139). Secondly, several national football associations, not least the German DFB, have lobbied and convinced their respective governments and especially their heads of government in order to exert some political pressure on the institutions of the Community, although mainly in form of public statements. In this regard, the joint statement of Gerhard Schröder and Tony Blair in the run-up to the Nice Summit 2000 - which expressed their concerns regarding a radical restructuring without enough consideration given to the peculiarities of football (Meier 2004: 14) - has been brought about also by several meetings of the DFB, representatives of leading German clubs and the German Chancellor, in which the 'football community' successfully specified possible adverse implications of a fully liberalised transfer regime for the most popular sport in Germany. ${ }^{16}$ Access to policy-makers has therefore been a crucial resource for the DFB and other national football associations. Undoubtedly, the common stance of national governments exerted indirect political pressure on the Commission, which can act with some degree of autonomy in competition policy but certainly does not take its decisions in a political vacuum. Thus, one can detect both engagement (attempts to modify the pressure of the ECJ's ruling and the Commission's claims) and more confrontational elements (attempts to resist and oppose pressures through organising political counter pressure) among the reactions of the DFB and FIFA.

Two of the most important aspects of the 'new transfer regime' agreed upon by FIFA and the Commission, besides the rules concerning contract stability, are the fixing of training compensations for players aged under 23 and the principle that clubs involved in training and education of young players should be rewarded. ${ }^{17}$ The payment of training compensation is in some ways a continuation of the old transfer fee payments for out-ofcontract players, albeit at a lower level and only with regard to young and amateur players. This adds to the judgement that the 'new transfer regime' agreed upon by FIFA and the Commission resembles not a complete overhaul of the old system but rather a case of 'heavy adjustment'. The introduction of compensation payments - crucial for smaller clubs - by the DFB, however, was ruled illegal in 2004 by the Regional Superior Court Oldenburg, which argued that they infringed on the freedom to choose a profession (Article 12, German Basic Law). In essence, this ruling constitutes a 'national Bosman ruling' for the realm of amateur football. Since the Court underscored that the DFB may have complied with FIFA rules, but that the rules of private organisations like FIFA in any case have to abide by national as well

\footnotetext{
${ }^{15}$ Interview with Gerhard Mayer-Vorfelder, then-President of the DFB, 2005.

16 ibid.

${ }^{17}$ Press Release European Commission, IP/02/824, 5 June 2002.
} 
as European law, one can foresee that this ruling (confirmed by the Regional Court of Appeal in 2005), will not end the debate, which have as their seminal reference the Bosman ruling of the ECJ. ${ }^{18}$

In sum, while the 'Bosman nationality regime' has led to a 'system transformation' in German (and other domestic) soccer, the 'Bosman transfer regime' has had less far-reaching implications, especially given the fact that contract stability is still maintained under the revised transfer rules. Here, the impact of change resulting from European integration might thus better be described as 'heavy adjustment'. The less significant degree of change in this case can be attributed to both somewhat less forceful top-down Europeanisation pressures (with the Commission soon relaxing its purism) and more considerable counter-pressures (associations and, to a lesser degree, clubs pursuing substantial lobbying efforts). ${ }^{19}$ The latter aspect indicates that 'Europeanisation' through European jurisdiction and institutions is far from being a one-way street.

\section{Case 3 - Broadcasting rights: the Bundesliga marketing system}

Over the past decade, the transformation of the broadcasting sector has had a significant impact on professional football in most European countries, including Germany. The sharp growth in the number of actors on the demand-side of the market with the advent of private television in Germany in the mid-1980s combined with the difficulty of increasing the supply of truly attractive football events led to very considerable increases in the prices charged for Bundesliga broadcasting rights (at least until the 'Kirch-crash'20), a development that has also been witnessed, to varying degrees, in the rest of Europe. Overall, broadcasting is a key element in the larger scale commercialisation of football in recent times. Broadcasting rights touch upon central power issues related to 'ownership' of the professional game. This commercialisation of sports (and above all football) in Europe has decisively fostered the intervention of EU institutions and Community law in the sector. The Commission's preoccupation with football has been driven by its need to monitor the broadcasting sector, in which it seeks to preclude practices that facilitate incumbents' to impede new entrants to the market (Weatherill 2003: 74).

One of the most contentious issues is concerned with the marketing system of broadcasting rights. An established commercial practice in European football, as well as the European sports sector more generally, is the central marketing and joint sale of broadcasting rights on behalf of individual participants. This system, which currently applies to both free-TV and pay-TV broadcasting of the Bundesliga, offers prospective buyers only the opportunity to compete for one package which comprises a league's entire output. Purchasers are unable to conclude deals with individual clubs. Such collective selling is an equalising arrangement through which revenues are distributed more evenly than in a decentralised model. In the latter system the allegedly more attractive clubs would take significantly more of the pie than smaller clubs. The main argument in favour of the collective system is that it helps sustain vibrant (inter-club) competition, a crucial element of any sporting activity. For instance, broadcasting rights for the Bundesliga, the English Premier League and the UEFA Champions League are marketed centrally by the DFB/DFL, the FA and UEFA, respectively.

\footnotetext{
${ }^{18}$ Ruling of the Regional Superior Court Oldenburg/Urteil des LG Oldenburg, Az.: 13 O 1195/04, 29 October 2004. The Federal Court of the DFB had to abide by this ruling and abolished these compensation payments in August 2006. See Kicker, 28 August 2006.

19 These counter-pressures to some degree resemble what has been termed a 'policy upload' in the Europeanization debate, see Börzel (2002). However, in most instances, policy uploads are framed as being 'national', made by member states of the EU. In our case, however, the upload was conducted by societal actors mostly.

${ }^{20}$ The Kirch Media Group, which acquired the Bundesliga broadcasting rights for the period 2000-2004, went into liquidation in April 2002. Only recently, media tycoon Leo Kirch has made a comeback through 'Sirius', a company of his own which will market the Bundesliga broadcasting rights for the 2009-2015 period. This agreement between the DFL and Sirius guarantees revenues of 3 billion Euro for the 36 Bundesliga clubs over that period, hence about 500 million Euro annually, which means a reasonable increase from the current 420 million Euro per season.
} 
From the perspective of EU law two issues were important here: firstly, whether the prevention of clubs from entering into individual agreements with broadcasters amounts to a restriction of competition and thus falls within the scope of Article 81 (1) TEC; secondly, whether the collective selling of broadcasting rights is necessary to ensure the survival of the financially weaker participants in the league. If the above mentioned solidarity argument is accepted, an exemption under Article 81 (3) from the application of Article 81 (1) TEC may be granted (Parrish 2002: 9).

Although the Commission generally has very significant competencies in competition policy (see McGowan 2000), it had already insisted that it did not aspire to become a general sports competition policy regulator. The Commission also more and more deviated from an orthodox articulation of Articles 81-82 in its communications and became increasingly eager to show respect for the social and cultural benefits of sports in recent years (Weatherill 2003). Hence, overall the level of top-down pressures (exerted by the Commission here) was less significant than in the previous two sub-cases.

The DFB requested an exemption from the application of Article 81 with regard to the central marketing of television and radio broadcasting rights for professional football matches in Germany in 1999. This was an issue of crucial importance to the DFB. The latter was not only concerned about the balance of inter-club competition. If the Commission was to rule in favour of a decentralised model, the DFB and DFL were to lose substantial property rights over broadcasting. Aided by UEFA as well as German policy-makers and backed by a large majority of clubs, the DFB sought to reduce EU level adaptational pressures. Its reaction can thus be described as intervention/engagement. Such response is rational in view of the preferences on the part of the DFB/DFL, UEFA and most Bundesliga clubs and given the substantial misfit between the existing regime and that suggested by the Commission.

Under the German collective selling system the DFB leases the broadcasting rights to the DFL, which markets the rights and redistributes the revenues gained from the broadcasting contracts to the clubs. The contracts in question in the DFB request for exemption from Article 81 concerned the rights to show matches from the First and Second Bundesliga. The application for derogation from Article 81 was substantiated with reference to the solidarity function, which the central marketing system supposedly fulfils, in that funds are redistributed more fairly among clubs than under a decentralised system.

This stance is accepted by most officials from the DFB and DFL as well as the vast majority of clubs. Among the 36 professional German football clubs only Bayern München, Borussia Dortmund and Bayer Leverkusen favoured a decentralised marketing model, in view of their capacity to raise considerably greater revenues. Although these clubs sporadically threatened with exit options, such as a European breakaway league, during the course of discussions all clubs eventually accepted the collective selling system. Later, however it was revealed that Bayern München mainly came on board because of a 'secret' marketing treaty with the Kirch-Group, which had secured the rights for the period 2000-2004. In this agreement Bayern München was compensated for lost revenues by foregoing individual marketing arrangements. As a result, the club de jure agreed to the central marketing model, while de facto securing the financial status of a decentralised system. This can be regarded as the introduction of elements of decentralised marketing through the back door (Kruse and Quitzau 2003: 13-14).

In the DFB request for an exemption from EU antitrust rules, the DFB and the DFL made a considerable effort to influence matters. They mainly sought to assert their preferences via UEFA. Former DFB President Mayer-Vorfelder was well placed in that respect as a member of the UEFA Executive Committee and the Executive Committee Working Group on matters related to the European Union. Within the UEFA framework DFB officials also participated directly in talks with representatives from the European Commission, members of the European Parliament and national ministers responsible for sport. In addition, top DFB officials cultivated direct relations with the Commissioners Reading and Monti. The DFB mainly used UEFA as a channel also because the latter was - simultaneously to the DFB 
case - involved in talks with the Commission as it had applied for an exemption from Article 81 concerning the collective marketing of commercial rights to the UEFA Champions League. Lobbying (via UEFA) has retrospectively been viewed as an effective method. ${ }^{21}$ Rather than applying direct (political) pressure, it was important in the discussions with the Commission and other EU circles to bridge certain knowledge gaps and to specify the implications of a vigorous application of Community antitrust rules to professional football in Germany. In addition, a certain amount of political pressure spilling over from the Bosman case and the subsequent talks concerning transfer rules $^{22}$ provided an additional rationale for the Commission decision to exempt the new system for marketing Bundesliga broadcasting rights. These logics also have to be seen against the background of growing anxieties on the part of the Commission in recent years to show respect for the social and cultural benefits of sport and its decreasing desire to get involved in sport policy (Weatherill 2003).

In January 2005 the Commission closed the case in view of certain commitments made by the DFL. Most significantly, media rights are offered in several packages in a transparent and non-discriminatory procedure. However, the new marketing system for Bundesliga broadcasting rights contains core demands of the DFB/DFL. The new model has been described as 'essentially a centralised system of marketing broadcasting rights with some decentralised elements on the fringes ${ }^{23}$. Even though this interpretation may be slightly optimistic, collective marketing of TV rights will broadly continue in one important aspect: clubs have only limited scope for selling their games. ${ }^{24}$ Overall these changes, spurred by EUlevel pressures, can be described as 'partial/modest adjustments', since only moderate alterations were made and important policy cores remained (largely) untouched.

\section{Case 4 - The Champions League}

So far we have predominantly looked at the adaptational pressures stemming from the European Union and the transnational and specifically German responses toward these pressures. In contrast, this section deals more with transnationally and domestically induced changes which have a significant bearing on the policies, structures and attitudes governing German (professional) football. The most important factor in that respect is the UEFA Champions League. Since the early 1990s there has been increasingly strong pressure on UEFA from the big European clubs and media groups to expand European club-level football competition in order to exploit its commercial potential. UEFA welcomed such ideas given the possibility of (further) raising its profile and status. As a result, UEFA enlarged the European Champion Clubs' Cup in 1992/1993 to include a league format, which has subsequently been called the 'Champions League'. Again at the initiative of media companies and the largest European clubs, which at times mildly threatened with the exit option (a European breakaway league), the league format was expanded in 1997, a step that was acquiescenced by UEFA. This allowed for more participants and increased the number of matches played, thus raising revenues.

Once established, the Champions League has itself become a source of Europeanisation, thus setting off a 'second round' of Europeanisation (Bugdahn 2005: 183). It has turned into a real focal point for the more competitive Bundesliga clubs, a development paralleled across other European football leagues. The rationale is two-fold. First, the participation in the Champions League is financially very lucrative. For example, in the season 2002/2003 Borussia Dortmund earned 33.7 million EUR (27.1 per cent of its total revenue) by merely reaching the second group stage in the Champions League. And in the season 2000/2001

\footnotetext{
${ }^{21}$ Interview with Gerhard Mayer-Vorfelder, then-President of the DFB, 2005.

${ }^{22}$ Statements by Gerhard Schröder and Tony Blair as well as provisions in the Amsterdam Declaration emphasised the need for EU institutions to listen to sports associations when important questions affecting sports are at issue.

${ }^{23}$ Interview with Dr. Christian Hockenjos, Managing Director at Borussia Dortmund, by telephone, January 2005.

${ }^{24}$ Clubs can sell their games for various media only after the match. Time frames for selling these rights differ across the different media. For full details see European Commission (2005).
} 
Bayern München gained 41.25 million EUR - almost twice as much as through total national TV revenues - by winning the Champions League. It can be argued that, due to the less lucrative different domestic TV-marketing conditions, participation in the Champions League is even more important for the top German clubs than for their English, Spanish or Italian rivals in order to stay competitive on the European level. English clubs can draw on huge earnings through their massive national broadcasting contracts. Top Italian clubs can raise very considerable revenue because the pay-TV sector is decentralised. ${ }^{25}$ And in Spain both free- and pay-TV is marketed on an individual basis, which benefits the most attractive teams disproportionately.

Secondly, the Champions League has also become a focal point for the bigger German (and other European) clubs because it has developed into a top brand. Part of the success story is that it in 2003-04 it contracted eighty-two TV partners in about 230 countries and islands and was able to increase its world-wide audience/broadcasting quota by (another) 9 per cent. In addition, Champions League matches have generated a higher average attendance than games in the biggest domestic leagues. ${ }^{26}$ Another indicator for the development of the Champions League brand is the continuity and fidelity of its sponsors: Ford, Mastercard and Amstel have all sponsored the Champions League from the outset or joined shortly after. Sony is also developing into a long-term partner. These companies all seem to regard their substantial contributions as profitable investments. A different sign of successful brandbuilding is the receipt by the Champions League of the TV industry's 'Oscar' awarded through the Broadcast Design Association for the best European appearance in the sports business in 2004. These 'soft' factors again have substantial positive financial implications for clubs taking part in the Champions League, for example in terms of sponsoring and merchandising, even though the impact of Champions League participation on these areas is difficult to measure. Overall, our interviewing of officials at the bigger Bundesliga clubs has revealed that - due to the above developments - the Champions League brand and its monetary implications have generated substantial appeal to them. Clubs like Borussia Dortmund and Bayer Leverkusen are aware that their performances in the Champions League have considerably raised their images nationally and internationally and that their membership in the G-14 forum is primarily owing to that. Overall the Champions League has altered the economic structure of European club football. Given domestic (broadcasting) background conditions, it is of particular appeal to Bundesliga clubs.

There is another aspect which is fostered by the Champions League (and by the increase of foreign-born players following from Bosman): the potential development of a 'European public space' (Brown 2000: 142). It has been noted that in contrast to processes on the level of elites, the general public is still for the most part inward-looking. As noted by Kohler-Koch (2002: 6), language barriers, strong national or local identities and traditions hold back the development of such transnational public space. The argument here is that football plays an important role in forming allegiances and identities at the national, local and supranational level, as it draws on an emotional investment by the supporter. If football is indeed an important expression of supporters' (collective) identities, cultural diversities could be given a more positive expression through football, and more 'European' allegiances could be reinforced. If fans' teams are increasingly composed of foreign-born (European) players, as is the case across the Bundesliga, and as their favourite players are gradually more non-native Europeans - such as the popular Dutch Rafael van der Vaart, the Belgian Daniel van Buyten or the Frenchman Willy Sagnol - this is likely to challenge existing identity patterns. As noted by the Economist, 'over the past decade European football teams have turned into a living, breathing embodiment of European integration'. ${ }^{27}$ Such tendencies are also reinforced by high audience quotas of Champions League games and the positive imagery and brand as well as high status attached to European-level competitions more generally. As for the

\footnotetext{
${ }^{25}$ Juventus Turin has allegedly made 93 million EUR through pay-TV during one season in the past: interview with Karl-Heinz Rummenigge, Chairman Executive Board, FC Bayern München AG, by telephone, December 2004.

${ }^{26}$ Between 1992/1993 and 2003/2004 the Champions League has generated an average attendance of 37.073 , more than any national football league during that period.

${ }^{27}$ Economist, 29 May 2003, 55.
} 
German case, no data or studies examining this argument more closely are known to the authors ${ }^{28}$, and the level of change is difficult to measure. Judging from media coverage and preliminary interviewing, it can be suggested that the impact of the Champions League in that respect may be quite substantial. Of course, these tentative findings do not replace proper empirical research on this issue, which would however go beyond the scope of this article.

\section{Case 5 - The G-14}

Going beyond processes of 'EU-Europeanisation' allows transnational dynamics, which emanate from football clubs, to come into play. Most remarkably, in the context of new technological (broadcasting) and legal (EU) developments and given the new financial dimensions of professional football (Champions League), new forms of European transnational networks have evolved, most prominently the so-called G-14.

The G-14 is a self-selected and self-recruiting interest group of today 18 big European football clubs. Its legal structure is that of a European Economic Interest Group (EEIG), which means that it is embedded in the instruments of the Community for facilitating and encouraging transnational cooperation between firms (as it was originally intended by the Community). That makes it, above all, a lobby group on behalf of the mainly commercial (common) interests of leading European clubs. Of great importance for the formation of the G-14 was the proposal of the Italian media organisation Media Partners in 1998 to establish a European Super League, a break-away league, in order to generate higher revenues from European-wide competitions than under the scheme of the UEFA Champions League (Parrish 2002: 11). Although UEFA countered with a change of format of the Champions League (Kruse and Quitzau 2003: 15) that appeased the big clubs ${ }^{29}$, the G-14 took steps to formalise and in 2000, constituted itself officially as the European lobby group ' $G-14$ ' with a General Manager who had been a key figure in the logistical organisation of UEFA Champions League before (Ducrey et al. 2003: 61).

Three German clubs are members of the G-14: Bayern München from its starting, Borussia Dortmund was invited to join in 1999 and Bayer Leverkusen in 2002. At the Management Committee, the de facto leading organ of the G-14, which generally sets the agenda, the 'German voice' has been for some time Vice Chairman Karl-Heinz Rummenigge, who through his position at Bayern München and his involvements with the DFL and FIFA has sometimes been named the 'ambassador of the G-14'.

The G-14 generated dynamics at three levels - vis-à-vis the European Commission, vis-à-vis UEFA/FIFA and 'inward-looking' among its members - thereby contributing to Europeanisation processes in the realm of football. In 2001, the G-14 opened an office in Brussels. This choice of place also reflected the growing awareness in football circles that the European Union has become a centre of gravity or at least a power centre for football. ${ }^{30}$ For the $\mathrm{G}-14$, it also mirrors the fact that the Commission has been regarded by the leading clubs as a potential ally (vis-à-vis the various associations) in reforming football according to the 'business perspective' (Ducrey et al. 2003: 34). Interestingly, while the G-14 has not been recognised by either UEFA or FIFA as an official organisation, the European Commission has not acted in a reserved manner and allowed the G-14 to explain its position as 'employer' of footballers in the talks between FIFA and the Commission about a new transfer regime in 2001. Thus, the relationship between the G-14 and the Commission has been characterised to some degree by mutual recognition of the respective positions. It did not generate any discernible pressure or counter pressure, but it certainly has reinforced 'Europeanising'

\footnotetext{
${ }^{28}$ For the English context, see Brown (2000) and King (2000).

${ }^{29}$ As Kruse and Quitzau (2003: 15) put it, the introduction of more group matches increases the number of matches to be played and thus revenues for participating clubs.

${ }^{30}$ In 2003, the UEFA has also opened an office in Brussels to liaise with the EU.
} 
mechanisms within the G-14 because of the Commission's acceptance of the group as a legitimate football organisation.

The orientation of the G-14 towards Europe can be explained by reference to the creational powers of the EU as well as its members' interest in revenues from lucrative European competitions (the Champions League in reality and the breakaway Super League as a rather implicit threat to UEFA). UEFA, not surprisingly, has a somewhat distanced relationship to the G-14, but recent developments hint at its attempt to strengthen ties with European football clubs either to accommodate the G-14 or to weaken it. In this regard, the UEFA Club Forum was established in 2002 as an expert panel (with the status of an advisory body) with representatives from 102 European clubs as members. Similarly, the European Professional Football Leagues (EPFL), an association of 15 professional leagues founded in 1998, has recently become more vocal as it has been trying to establish itself as the fifty-third association alongside the various national associations within UEFA. These developments also show that German football officials have contributed to some counter trends to the G-14 as well, since the strengthening of the EPFL has been partially caused by leading actors of the DFL. ${ }^{31}$

Important from our point of view is that a more and more complex web of transnational networks and relationships has been established throughout the realm of European football, mainly through and with reference to the G-14 grouping. The G-14 itself thereby represents a qualitatively different type of transnationalism from those of UEFA or FIFA, since the latter are, above all, constituted through national associations (Lehmkuhl 2004: 182). The transnational character of the G-14, on the other hand, is based more on personal relationships between top executives, which have frequent contact with each other and act on the basis of interests which overlap for a good part; moreover, national regards tend to dissolve $^{32}$, in contrast to UEFA where national interests from time to time seem to be more important. The G-14, to sum it up, could level some pressure on FIFA/UEFA by promoting the interests of its member clubs vis-à-vis European institutions and the football associations themselves. Attempts of UEFA and other actors to accommodate some demands of football clubs within European football governance have been provoked by the $\mathrm{G}-14$. The grouping itself adds to the growing Europeanisation of football in Europe, because it generates a 'Europeanising', inward-directed dynamic through providing a trans-national platform for the articulation of common interests.

It would, however, be slightly exaggerated to see the G-14 grouping as first and foremost a socialising instance (emitting Europeanising impulses) for the clubs involved. The recent gestures of Bayern München, for instance, make quite clear that the clubs still have a strong instrumental view of the G-14 as a lobbying venue. If it is to be used as a tool to influence UEFA (regarding the selling of broadcasting rights of the Champions League) or institutions of the European Union (regarding the possibilities of a Salary Cap for players), the G-14 seems to be a promising venue. The latter case which articulates a specific German demand vis-à-vis other European clubs - for reasons of competitiveness, indicates however, that the G-14 has retained strong national bonds. Since most clubs in the G-14 have not shown a noticeable interest in Salary Caps, Bayern München has recently come to criticise the clubs involved for their egoism and moved towards engaging UEFA as a potential ally. ${ }^{33}$

These observations do by no means invalidate our claim that the G-14 is a forum in which the European level of political institutions and sports' associations is actively addressed; it only underscores that the European political and societal sphere has become a focal point of activity for German top football clubs as well.

\footnotetext{
${ }^{31}$ See 'Straub fordert direkte Mitsprache bei UEFA', in: ZDF.de, 30 November 2004.

32 Interview Christian Hockenjos, Managing Director at Borussia Dortmund, 2005, see also the Ducrey et al. (2003: 60).

${ }^{33}$ See, 'Rummenigge fordert Salary Cap', in Kicker Online, 17 November 2006.
} 
Table 1: The systematisation of Europeanisation processes in German football across sub-cases

\begin{tabular}{|c|c|c|c|c|c|c|}
\hline Sub-cases & $\begin{array}{c}\text { Source of } \\
\text { Europeanisation }\end{array}$ & $\begin{array}{c}\text { Strength of } \\
\text { Pressure/Dynamic }\end{array}$ & $\begin{array}{l}\text { Addressee/ } \\
\text { Affected } \\
\text { Actors }\end{array}$ & $\begin{array}{l}\text { Reaction to } \\
\text { Pressures }\end{array}$ & $\begin{array}{l}\text { Strength } \\
\text { of } \\
\text { Reaction }\end{array}$ & $\begin{array}{l}\text { Degree of } \\
\text { Change }\end{array}$ \\
\hline $\begin{array}{l}\text { Bosman I: } \\
\text { The } \\
\text { Nationality } \\
\text { Issue }\end{array}$ & $\begin{array}{l}\text { Top-down } \\
\text { through ECJ / } \\
\text { Commission }\end{array}$ & (Medium) to High & $\begin{array}{l}\text { DFB, } \\
\text { (Football } \\
\text { clubs) }\end{array}$ & $\begin{array}{l}\text { Formulation: no } \\
\text { role } \\
\text { Implementation: } \\
\text { mixture of } \\
\text { progressive and } \\
\text { conservative } \\
\text { transposition }\end{array}$ & Moderate & Transformation \\
\hline $\begin{array}{l}\text { Bosman II: } \\
\text { New Transfer } \\
\text { Regime }\end{array}$ & $\begin{array}{l}\text { Top-down } \\
\text { through ECJ / } \\
\text { Commission }\end{array}$ & Medium (to High) & $\begin{array}{l}\text { FIFA, } \\
\text { national } \\
\text { associations } \\
\text { (incl. DFB) }\end{array}$ & $\begin{array}{l}\text { Formulation: } \\
\text { engagement and } \\
\text { confrontation }\end{array}$ & High & $\begin{array}{l}\text { 'Heavy } \\
\text { adjustment' }\end{array}$ \\
\hline $\begin{array}{l}\text { Broadcasting } \\
\text { Rights }\end{array}$ & $\begin{array}{l}\text { Top-down } \\
\text { through } \\
\text { Commission }\end{array}$ & Medium & DFB/DFL & $\begin{array}{l}\text { Formulation: } \\
\text { Engagement }\end{array}$ & $\begin{array}{l}\text { (Relatively) } \\
\text { High }\end{array}$ & Adjustment \\
\hline \multirow[t]{2}{*}{$\begin{array}{l}\text { Champions } \\
\text { League }\end{array}$} & $\begin{array}{l}\text { Transnational / } \\
\text { bottom-up [still } \\
\text { privileged actors: } \\
\text { big clubs, media] }\end{array}$ & Medium (to High) & UEFA & $\begin{array}{l}\text { Acquiescence } \\
\text { and support }\end{array}$ & Medium & \multirow{2}{*}{$\begin{array}{l}\text { ('Heavy') } \\
\text { Adjustment } \\
\text { (hints at possible } \\
\text { transformation?) }\end{array}$} \\
\hline & $\begin{array}{l}\text { 'Champions } \\
\text { League' itself }\end{array}$ & $\begin{array}{l}\text { Medium } \\
\text { (Low to) Medium }\end{array}$ & $\begin{array}{l}\text { (big) clubs } \\
\text { European } \\
\text { public }\end{array}$ & $\begin{array}{l}\text { Support } \\
\text { Support }\end{array}$ & $\begin{array}{l}\text { Medium } \\
\text { Low? }\end{array}$ & \\
\hline \multirow[t]{3}{*}{ G-14 } & \multirow{3}{*}{$\begin{array}{l}\text { Transnational / } \\
\text { bottom-up [still } \\
\text { privileged actors: } \\
\text { reps of big clubs] }\end{array}$} & Low & $\begin{array}{l}\text { EU } \\
\text { Commission }\end{array}$ & Support & $\begin{array}{l}\text { Low (to } \\
\text { Medium) }\end{array}$ & \multirow[t]{3}{*}{ Adjustment? } \\
\hline & & Medium & UEFA / FIFA & $\begin{array}{l}\text { Confrontation } \\
\text { and engagement }\end{array}$ & $\begin{array}{l}\text { Medium } \\
\text { (to High) }\end{array}$ & \\
\hline & & High & $\begin{array}{l}\text { inward- } \\
\text { directed }\end{array}$ & $?$ & $?$ & \\
\hline
\end{tabular}

\section{Conclusions}

The above analysis indicates that our five sub-cases represent rather different Europeanisation processes (see Table 1). Bosman I is characterised by strong top-down EU pressures on the DFB (and German clubs) to change nationality restrictions, which were mediated through a mixture of progressive and conservative transposition, while domestic and transnational actors did hardly intervene in the policy formulation period. As a result, we have a high degree of change, adequately described as 'system transformation', which is indicated not least in the large share of UEFA residents playing in the Bundesliga. The second case, Bosman II, can be described as medium to strong European level/EU pressure on FIFA and national associations to alter the transfer regime. Domestic and transnational agents already became involved in the policy formulation phase and built up considerable opposition against the line pursued by the Commission. Hence, it was possible to prevent a complete overhaul of the transfer system, but (heavy) adjustments had to be made. Thirdly, as for the broadcasting case, we witnessed medium pressure from the Commission on the German Football Association and the German Football League to change the centralised marketing model. The DFB and DFL effectively engaged and opposed the Commission on this issue and thus managed to reduce Europeanisation pressures, as a result of which the current broadcasting system merely has to be adjusted.

Cases four and five are characterised by rather different sources of Europeanisation, emanating from domestic and above all transnational spheres. The Champions League case represents a more complex process in which big football clubs and media companies exerted considerable pressure on an acquiescencing and somewhat supportive UEFA for an 
extension and upgrading of European club competitions. The resulting Champions League, especially due to its very significant financial implications, has to some extent altered the economic structure of European club football, acting as a pull factor particularly to German clubs, given domestic (broadcasting) background conditions. However, the impact of the Champions League (together with the increase of foreign-born players following from Bosman) is more profound than that; it may also contribute to the development of a European public space, in terms of forming allegiances and identities on the level of ordinary citizens. Finally, the G-14 case is driven by transnational pressures from the biggest European football clubs with rather different reactions on the EU level, on the level of European/international football associations (UEFA and FIFA) and within the G-14 itself. While the Commission has been rather supportive, the UEFA tends to see the G-14 as a rival institution that needs to be somewhat held in check. Internally, the G-14 has witnessed certain socialisation processes (and the development of common perspectives). G-14 Europeanisation processes have proceeded rather unevenly, but nevertheless had a moderate impact on the German (and European) football regime.

We have aimed at exploring the applicability of Europeanisation concepts and categorisations - mainly derived from the analysis of political contexts - to other fields of social interaction. Overall, our systematisation of Europeanisation into different stages and categories has proven useful for an analysis of different Europeanisation processes in the area of German football. The last two sub-cases, which were characterised by considerable complexity, have indicated the boundaries of utility of our typology, as the variety of dynamics became increasingly difficult to capture. Categorisation (and thus implicitly conceptual parsimony) is always, to some extent, a trade-off with the complexity of empirical 'reality'.

Our analysis also adds to one of the most widely discussed issues in the Europeanisation debate, namely the causal relevance of the EU concerning domestic developments. If we look at the first three sub-cases in isolation, we have some scope for a comparative analysis, as these units are adequately homogenous. Values on the explanatory variable (the level of EU pressures) vary across these sub-cases between high (Bosman I) and medium (broadcasting). The three sub-cases indicate that the level of EU pressure indeed seems to have causal relevance. High EU pressures in Bosman I (accompanied with only medium intervening counter-reactions) have led to a transformation of the nationality regime. By contrast, only medium pressures in the case of broadcasting (albeit accompanied by stronger counter-reactions) has only led to (minor) adjustments of the existing broadcasting model. The Bosman II case also fits into this sequence: medium to high EU pressures met by strong intervening counter-reactions lead to heavy adjustment of the transfer regime. While this comparison suggests that the EU matters, it also indicates that control/intervening variables, such as domestic and transnational/societal responses, are also important factors to be reckoned with.

European Integration Studies benefit from an analysis of (German) football in several ways. Most importantly, it highlights the under-researched societal/transnational dimension of Europeanisation as a central theme in EU Studies. Our analysis of football has allowed us to draw attention to societal spheres and transnational agency as important aspects/properties of change in Europeanisation processes. This also enabled us to go beyond the conventional top-down (and bottom-up) approaches still dominating this (sub-)field, thus accounting for the complexity of the process. Needless to say that a more theoretically-driven analysis of sequencing patterns of top-down and bottom-up processes would add further value.

At the same time, our analysis contributed to ascertaining the utility of Europeanisation factors/categorisations - mainly derived from the analysis of political contexts - to explain dynamics in societal, i.e. rather non-political, contexts. In some ways, football confirms the knowledge about dynamics and mechanisms of Europeanisation that recent studies going beyond the conventional (top-down) perspective have gained. However, as cases 4 and 5 have especially indicated, new types of transnational agency might also enhance the need for new analytical instruments/categories. 


\section{References}

Börzel, T. (2001). Shaping States and Regions. The Domestic Impact of Europe, Cambridge: Cambridge University Press.

Börzel, T.A. (2002). 'Member State Responses to Europeanization', Journal of Common Market Studies, 40, pp. 193-214.

Brown, A. (2000). 'European Football and the European Union: Governance, Participation and Social Cohesion - Towards a Policy Research Agenda', Soccer and Society, 1, pp. 129-50.

Bugdahn, S. (2005). 'Of Europeanization and Domestication: the Implementation of the Environmental Information Directive in Ireland, Great Britain and Germany', Journal of European Public Policy, 12, pp. 177-99.

Caporaso, A. and Jupille, J. (2001). 'The Europeanization of Social Policy and Domestic Political Change', in M. Green Cowles, J. Caporaso and T. Risse (eds.), Transforming Europe. Europeanization and Domestic Change, Ithaca, NY: Cornell University Press.

Collier, D. (1995). 'Translating Quantitative Methods for Qualitative Researchers: The Case of Selection Bias', American Political Science Review, 89, pp. 461-66.

Croci, O. (2001). Taking the Field: the EC and the Governance of European Football, Paper presented at the $7^{\text {th }}$ ECSA-USA International Conference, Madison (Wisconsin), 31 May - 2 June.

Croci, O. and Forster, J. (2004). 'Webs of Authority: Hierarchies, Networks, Legitimacy, and Economic Power in Global Sport Organizations' in G.T. Papanikos (ed.), The Economics and Management of Mega Athletic Events: Olympic Games, Professional Sports, and Other Essays, Athens: ATINER.

Deutsch, K. et al. (1957). Political Community and the North Atlantic Area, Princeton: Princeton University Press.

Ducrey, P., Ferreira, C.E., Huerta, G. and Marston, K.T. (2003). UEFA and Football Governance, Project Work, Neuchâtel: CIES.

Dyson, K. (1999). 'EMU as Europeanization: Convergence, Diversity and Contingency', Journal of Common Market Studies, 38, pp. 645-66.

European Commission (2005). Details of broadcasting rights commitments by the German Football League, Press Release MEMO/05/16, Brussels, 19 January.

Feron, E. (2004). 'Anti-Globalization Movements and the European Agenda. Between Dependence and Disconnection', Innovation, 17, pp. 119-27.

Foster, K. (2000). 'European Law and Football: Who's in Charge?', in J. Garland et al. (eds.), The Future of Football - Challenges for the Twenty-First Century, London: Frank Cass.

Haas, E. (1958). The Uniting of Europe: Political, Social and Economic Forces, 1950-7, London: Stevens.

Havemann, N. (2005). Fußball unterm Hakenkreuz. Der DFB zwischen Sport, Politik und Kommerz. Frankfurt: Campus.

Héritier, A., Kerwer, D., Knill, C., Lehmkuhl, D. and Teutsch, M. (2001). Differential Europe. New Opportunities and Constraints for National Policy-Making, Lanham: Rowman and Littlefield.

George, A. and McKeown, T. (1985). 'Case Studies and Theories of Organizational Decision Making', Advances in Information Processing in Organizations 2, pp. 21-58.

King, A. (2000). 'Football Fandom and Post-national Identity in the New Europe', British Journal of Sociology, 54, pp. 419-42. 
Kohler-Koch, B. (2002) The Transformation of Governance in Europe, Paper presented at the Colloquium 'The Future of Europe Challenges Ahead', Maastricht University, 6 September, online available <www.sowi.uni-mannheim.de/lehrstuehle/lspol2/ service/dl/Maastricht-Sept02.doc>, last accessed July 2005.

Knill, C. (2001). The Europeanisation of National Administrations, Cambridge: Cambridge University Press.

Knill, C. and Lehmkuhl, D. (2002). 'The National Impact of European Union Regulatory Policy: Three Europeanization Mechanisms', European Journal of Political Research, 41 , pp. 255-80.

Kruse, J. and Quitzau, J. (2003). Fußball-Fernsehrechte: Aspekte der Zentralvermarktung, Universität der Bundeswehr Hamburg, Fächergruppe Volkswirtschaftslehre, Diskussionspapier 18.

Ladrech, R. (1994). 'Europeanisation of Domestic Politics and Institutions: The Case of France', Journal of Common Market Studies, 32, pp. 69-88.

Lehmkuhl, D. (2004). 'Der lange Schatten staatlichen Rechts: Verrechtlichung im transnationalen Sport', in B. Zangl and M. Zürn (eds.), Verrechtlichung - Baustein für Global Governance? Bonn: Dietz.

Lodge, M. (2002). 'Varieties of Europeanisation and the National Regulatory State', Public Policy and Administration, 17, pp. 43-67.

Mayer, F.C. and Palmowski, J. (2004). 'European Identities and the EU - The Ties that Bind the Peoples of Europe', Journal of Common Market Studies, 42, pp. 573-98.

McGowan, F. (2000). 'Competition Policy. The Limits of the European Regulatory State', in $\mathrm{H}$. Wallace and W. Wallace, Policy-Making in the European Union, Oxford: Oxford University Press, $4^{\text {th }}$ Edition.

Meier, H.E. (2004). Von Bosman zur Kollektivvereinbarung? Die Regulierung des Arbeitsmarktes für Profifußballer, online available <http://www.unipotsdam.de/u/ls_verwaltung/Forschung/Von\%20Bosman\%20zur\%20Kollektivver einbarung_.pdf >, last accessed July 2005.

Menz, G. (2003). 'Re-regulating the Single Market: National Varieties of Capitalism and Their Responses to Europeanization', Journal of European Public Policy, 10, pp. 53255.

Niemann, A. (2006). Explaining decisions in the European Union, Cambridge: Cambridge University Press.

Niemann, A. and Brand A. (2008 forthcoming). 'The Impact of European Integration on Sport: The Case of German Football', Sport in Society 11.

Olsen, J.P. (2002). 'The Many Faces of Europeanisation', Journal of Common Market Studies, 40, pp. 921-52.

Parrish, R. (2003). Sports Law and Policy in the European Union, Manchester: Manchester University Press.

Parrish, R. (2002). 'Football's Place in the Single European Market', Soccer and Society, 3, pp. 1-21.

Radaelli, C.M. (2004). 'Europeanisation: Solution or Problem?', European Integration online Papers, 8, online available <http://eiop.or.at/eiop/index.php/eiop/issue/ archive>, last accessed October 2007.

Radaelli, C. (2000). 'Whither Europeanisation? Concept Stretching and Substantive Change', European Integration online Papers, 4, online available 
$<$ http://eiop.or.at/eiop/index.php/eiop/issue/archive>, last accessed October 2007.

Risse, T. (2004). 'Social Constructivism and European Integration', in T. Diez and A. Wiener (eds.), European Integration Theory, Oxford: Oxford University Press.

Risse, T. (2002). 'Transnational Actors in World Politics', in W. Carlsnaes et al. (eds.), Handbook of International Relations, London: Sage.

Risse, T. Caporaso, J. and Green Cowles, M. (2001). 'Europeanization and Domestic Change. Introduction', in M. Cowles, J. Caporaso and T. Risse (eds.), Transforming Europe, Ithaca NY: Cornell University Press.

Schmidt, V. (2002). 'Europeanization and the Mechanics of Economic Policy Adjustments', Journal of European Public Policy, 9, pp. 894-912.

Shaw, D. (1987). Fútbol y Franquismo, Madrid: Alianza.

Stone Sweet, A. and Sandholtz, W. (1997). 'European Integration and Supranational Governance', Journal of European Public Policy, 4, pp. 297-317.

Vink, M. (2002). What is Europeanization? And other Questions on a New Research Agenda, Paper for the Second YEN Research Meeting on Europeanisation, University of Bocconi, Milan, 22-23 November.

Wagg, S. (1995). Giving the Game Away: Football, Politics, and Culture on Five Continents. London/New York: Leicester University Press.

Wallace, H. (2000). 'Europeanisation and Globalisation: Complementary or Contradictory Trends?', New Political Economy, 5, pp. 369-82.

Weatherill, S. (2003). "Fair Play Please!" Recent Developments in the Application of EC Law to Sport', Common Market Law Review, 40, pp. 51-93.

Winn, N. (2003). 'The European Union's External Face: The 'Europeanisation' of JHA and CFSP', Perspectives on European Politics and Society, 4, pp. 147-66. 